\title{
Nitrogen assimilation in the bromeliad Ananas comosus var. ananassoides (Baker) Coppens \& F.Leal grown in vitro with different sources of inorganic nitrogen
}

Priscila Primo Andrade Silva1, (D) Ivomar Aparecido Medina², (D) Jorge Luiz Marx Young and (D) Vívian Tamaki²,3

Received: 15.07.2020; accepted: 11.10 .2020

How to cite: Silva, P.P.A., Medina, I.A., Young, J.L.M., \& Tamaki, V. 2020. Nitrogen assimilation in the bromeliad Ananas comosus var. ananassoides (Baker) Coppens \& F.Leal grown in vitro with different sources of inorganic nitrogen. Hoehnea 47: e962019. http://dx.doi.org/10.1590/2236-8906-96/2019

\begin{abstract}
Nitrogen assimilation in the bromeliad Ananas comosus var. ananassoides (Baker) Coppens \& F.Leal grown in vitro with different sources of inorganic nitrogen). Ananas comosus var. ananassoides (Baker) Coppens \& F.Leal is a native ornamental bromeliad of the endangered biome Cerrado. Therefore, approaches aimed at the preservation of this species, such as in vitro cultivation and micropropagation are needed. Nitrogen $(\mathrm{N})$ is absorbed by plants, mainly as $\mathrm{NO}_{3}{ }^{-}$and/or $\mathrm{NH}_{4}^{+}$, and assimilated into amino acids. The aim of this work was to evaluate the $\mathrm{N}$ assimilation in this bromeliad. Plants were grown in vitro for seven months in modified MS medium with 15, 30, 60, and $90 \mathrm{mM}$ of $\mathrm{N}$ as $\mathrm{NO}_{3}^{-}, \mathrm{NH}_{4}^{+}$or $^{-} \mathrm{NH}_{4} \mathrm{NO}_{3}$, and then transferred to ex vitro conditions for acclimatization. Plants grown with $\mathrm{NH}_{4}^{+}$had high mortality. During acclimatization plants cultivated with 30,60 , and $90 \mathrm{mM}$ of $\mathrm{N}$ as $\mathrm{NH}_{4} \mathrm{NO}_{3}$ showed higher biomass. With regard to $\mathrm{N}$ assimilation, GS and $\mathrm{NR}$ showed the highest activity in plants cultivated with $\mathrm{NH}_{4} \mathrm{NO}_{3}$, whereas plants cultivated with $\mathrm{NH}_{4}^{+}$had the highest GDH activity. Consequently, in vitro and ex vitro cultivation of this species with $60 \mathrm{mM} \mathrm{N}$ as $\mathrm{NH}_{4} \mathrm{NO}_{3}$ is recommended.

Keywords: acclimatization, Bromeliaceae, in vitro culture, micropropagation, pineapple
\end{abstract}

RESUMO - (Assimilação de nitrogênio na bromélia Ananas comosus var. ananassoides (Baker) Coppens \& F.Leal cultivada in vitro com diferentes fontes de nitrogênio inorgânico). Ananas comosus var. ananassoides (Baker) Coppens \& F.Leal é uma bromélia ornamental nativa do Cerrado, um bioma ameaçado de extinção, sendo necessários estudos para sua preservação, como o uso de micropropagação. O nutriente nitrogênio (N) é absorvido pelas plantas, principalmente, como $\mathrm{NO}_{3}^{-}$e/ou $\mathrm{NH}_{4}^{+}$e é assimilado em aminoácidos. O objetivo deste trabalho foi avaliar a assimilação de $\mathrm{N}$ nesta bromélia. As

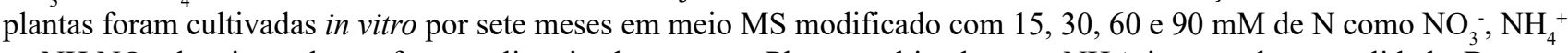
ou $\mathrm{NH}_{4} \mathrm{NO}_{3}$, depois as plantas foram aclimatizadas ex vitro. Plantas cultivadas com $\mathrm{NH}_{4}^{+}$tiveram alta mortalidade. Durante a aclimatização, plantas cultivadas com 30, 60 e $90 \mathrm{mM}$ de $\mathrm{N}$ como $\mathrm{NH}_{4} \mathrm{NO}_{3}$ apresentaram maior biomassa. Em relação à assimilação do N, GS e NR apresentaram as maiores atividades em plantas cultivadas com $\mathrm{NH}_{4} \mathrm{NO}_{3}$, e as adubadas apenas com $\mathrm{NH}_{4}^{+}$tiveram alta atividade da GDH. Consequentemente, recomenda-se cultivar esta espécie in vitro e ex vitro com $60 \mathrm{mM}$ de $\mathrm{N}$ como $\mathrm{NH}_{4} \mathrm{NO}_{3}$.

Palavras-chave: abacaxi, aclimatização, Bromeliaceae, cultivo in vitro, micropropagação

1. Part of the Masters' Dissertation of the first Author

2. Instituto de Botânica, Avenida Miguel Estéfano, 3687, 04045-972 São Paulo, SP, Brasil

3. Corresponding author: vtamaki@ibot.sp.gov.br 


\section{Introduction}

Ananas comosus var. ananassoides (Baker) Coppens \& F.Leal, also known as field pineapple (Silva 2006, Crestani et al. 2010), is a terricolous bromeliad, native to Cerrado (Proença \& Sajo 2007). This species, like other bromeliads from this biome, has ornamental and landscape potential (Zucchi et al. 2019) but is still little explored economically (Silva 2006, Souza et al. 2007, Crestani et al. 2010). It is characterized by the presence of leaves covered with trichomes, well-developed absorbent roots as it is terricolous, a globose inflorescence bearing bracts with complete and small flowers, and an 8-10 cm and creamy to pink-yellow infructescence located in the apical part of the stem which can measure up to $80 \mathrm{~cm}$ (Paula \& Silva 2004, Souza et al. 2007). This ornamental bromeliad has been traditionally cultivated for export as a cut flower (Souza et al. 2012). Besides its economic importance as an ornamental plant, this species is native to a biome that belongs to the 34 global biodiversity hotspots, which are areas of high biodiversity and endemism (Myer et al. 2000, Orme et al. 2005). Therefore, conservation measures of their species are important and necessary. One way of contributing to the biome preservation, could be through the development of micropropagation studies of plants.

A key factor for in vitro cultivation is the selection of a suitable culture medium for the growth and development of the species of interest (Bunn et al. 2011). Most culture mediums are basic formulations such as the MS medium formulated by Murashige and Skoog (1962), which is the most commonly used for in vitro culture (Aranda-Peres et al. 2009, Werner et al. 2010, Lima et al. 2020). Among the nutrients, that compose the culture medium, the nitrogen $(\mathrm{N})$ is required in a major amount by most plants (Marschner \& Marschner 2012, Buchanan et al. 2015, Esteban et al. 2016).

Ammonium $\left(\mathrm{NH}_{4}^{+}\right)$and nitrate $\left(\mathrm{NO}_{3}^{-}\right)$ions are the most available $\mathrm{N}$ sources in the soil solution to be absorbed by plant roots (Epstein \& Bloom 2006, Marschner \& Marschner 2012, Esteban et al. 2016, Hachiya \& Sakakibara, 2017). The roots absorb these two ions by high- (HATS) and low(LATS) affinity transporters that are specific for each N form (Miller et al. 2007, Kraiser et al. 2011, Xu et al. 2012). Once absorbed, the $\mathrm{N}$ can be either readily assimilated in the roots or stored in the vacuoles, and also transported via the xylem to be assimilated in the shoot (Rennenberg et al. 2010, Braun et al. 2013). To enter in the assimilation pathway, the $\mathrm{N}$ in the form of $\mathrm{NO}_{3}^{-}$is reduced to nitrite $\left(\mathrm{NO}_{2}^{-}\right)$ in the cell cytosol by the nitrate reductase (NR), and then transported inside the plastid, where it is reduced to $\mathrm{NH}_{4}^{+}$by the nitrite reductase (NiR) (Marschner \& Marschner 2012, Taiz \& Zeiger 2013). The $\mathrm{NH}_{4}^{+}$originated is assimilated into glutamine (GLN) by the glutamine synthetase (GS), and then transformed into glutamate (GLU) by the glutamine oxoglutarate aminotransferase (GOGAT) (Marschner \& Marschner 2012, Taiz \& Zeiger 2013, Buchanan et al. 2015,
Liu \& Wirén 2019). In addition, the glutamate dehydrogenase (GDH), which normally catalyzes the reversible deamination of glutamate to 2-oxoglutarate, it might be collaborating in the assimilation of $\mathrm{N}$ into GLU under certain conditions (Skopelitis et al. 2006, Andrews et al. 2013, Luo et al. 2015). Subsequently, GLU and GLN will be used for the biosynthesis of other organic $\mathrm{N}$ forms essential for cellular metabolism, promoting plant growth and development (Marschner \& Marschner 2012, Andrews et al. 2013). Although the process of $\mathrm{N}$ assimilation in plants is wellknown, much information is still lacking to better understand this metabolic activity (Krapp 2015).

After in vitro production, plants need to be acclimatized before their transfer to the field (Grattapaglia \& Machado 1998, Berilli et al. 2011). Transfer to ex vitro conditions implies morphological and physiological changes that confer plants resistance to external environmental factors, such as to increased transpiration and luminous flux, temperature fluctuations, interaction with microorganisms, among others (Calvete et al. 2002, Hartmann et al. 2002, Albert 2004). Sudden changes in these conditions might be limiting for the propagation of some species (Grattapaglia \& Machado 1998, Bregonci et al. 2008, Berilli et al. 2011), and therefore, highlight the importance of acclimatization studies.

Some studies showed that the joint use of $\mathrm{NH}_{4}^{+}$and $\mathrm{NO}_{3}$ - promotes plant growth (Hachiya \& Sakakibara, 2017), including some bromeliad species, such as Ananas comosus (L.) Merr., Vriesea fosteriana L.B.Sm., Tillandsia pohliana Mez, and Nidularium minutum Mez (Endres \& Mercier 2001, Nievola et al. 2001, Tamaki \& Mercier 2007, Silva et al. 2010, Andrade \& Tamaki 2016). Some studies that cultivated A. comosus var. ananassoides in vitro in MS medium with modified concentrations of $\mathrm{NO}_{3}{ }^{-}$and $\mathrm{NH}_{4}^{+}$proved that $\mathrm{NH}^{+}$is not appropriate for the growth of this species (Dias et al. 2008, Dias et al. 2010, Dias et al. 2011a, b, Carvalho et al. 2012, Silva \& Tamaki 2012, Dias et al. 2013, Silva et al. 2017). However, there are no studies published hitherto that evaluate the influence of different sources of inorganic nitrogen on the growth, nitrogen assimilation, and ex vitro acclimatization of this bromeliad. Therefore, this study aimed at evaluating the growth and nitrogen assimilation in the bromeliad A. comosus var. ananassoides cultivated in vitro and acclimatized ex vitro with different sources and concentrations of inorganic $\mathrm{N}$.

\section{Material and methods}

Plant material - Seeds of Ananas comosus var. ananassoides (Baker) Coppens \& F. Leal, whose fruits were harvested at the Biological Reserve of Mogi Guaçu, São Paulo State, Brazil, were used in the experiments.

Obtaining nodal segments - Approximately 1,000 nodal segments were obtained from in vitro germination of approximately 400 seeds. These seeds were previously 
disinfested and subsequently deposited in Petri dishes for germination according to Araujo et al. (2012). Posteriorly, the seedlings were transferred to $250 \mathrm{~mL}$ glass flasks containing $30 \mathrm{~mL}$ of modified Murashige \& Skoog (1962) (MS) culture medium with only $50 \%$ of macronutrient concentration (MS/2), $30 \%$ of sucrose and $5 \%$ of agar. Seedlings were maintained in a culture room with a $12 \mathrm{~h}$ photoperiod, $30 \mu \mathrm{mol} \mathrm{m}{ }^{-2} \cdot \mathrm{s}^{-1}$ of photosynthetically active radiation, and a temperature of $26 \pm 2{ }^{\circ} \mathrm{C}$ for two months. Leaves of plants grown in aseptic conditions were cut leaving the shoot with only $1 \mathrm{~cm}$ long, and transferred to $500 \mathrm{ml}$ glass flasks containing $40 \mathrm{ml}$ of $\mathrm{MS} / 2$ culture medium, in which they remained in the absence of light for five months to obtain nodal segments.

Plants obtained from nodal segments and grown in vitro with different nitrogen sources and concentrations - The nodal segments obtained were isolated and maintained in $350 \mathrm{~mL}$ glass flasks containing $30 \mathrm{~mL} \mathrm{MS} / 2$ culture medium for two months in a culture room under the same conditions described previously. After this period, the grown plants were transferred to $350 \mathrm{~mL}$ glass flasks (five plants per flask) containing $30 \mathrm{~mL}$ of modified MS medium with different $\mathrm{N}$ sources $\left(\mathrm{NH}_{4}^{+}, \mathrm{NO}_{3}^{-}\right.$and $\left.\mathrm{NH}_{4} \mathrm{NO}_{3}\right)$ and concentrations $(15,30,60$ and $90 \mathrm{mM})$ and were maintained in a culture room for seven months. After three months, the plants were transferred to a new culture medium with the same concentrations to avoid nutritional deficiencies and/or $\mathrm{pH}$ changes. After seven months, 24 hours before the harvest of the plant material, the plants were transferred to $350 \mathrm{~mL}$ glass flasks containing $30 \mathrm{~mL}$ modified MS medium with the different $\mathrm{N}$ sources and concentrations, to guarantee the $\mathrm{N}$ supply. Afterward, the shoot and root fresh and dry weights, the endogenous content of ammonium, nitrate and photosynthetic pigments, and the activity of nitrate reductase (NR), glutamine synthetase (GS), and NADH-dependent glutamate dehydrogenase (NADH-GDH) were evaluated. For the enzyme analysis, plants were harvested three hours after the beginning of the light period in the culture room. The dry weights of the shoots and roots were determined by drying the samples in an oven at $60^{\circ} \mathrm{C}$ to constant weight.

Plant acclimatization- After seven months of in vitro culture with different $\mathrm{N}$ sources and concentrations, the plants were acclimatized in $600 \mathrm{~mL}$ plastic pots (10 plants per pot) containing washed sand as substrate. Leaves and roots were irrigated every 15 days with $40 \mathrm{~mL}$ of nutrient solution consisting of a modified MS formulation without sucrose and agar and different $\mathrm{N}$ sources $\left(\mathrm{NH}_{4}^{+}, \mathrm{NO}_{3}^{-}\right.$and $\left.\mathrm{NH}_{4} \mathrm{NO}_{3}\right)$ and concentrations $(15,30,60$ and $90 \mathrm{mM})$. Plants were maintained in culture room for three months under the same controlled conditions described above. After this period, the shoot and root fresh and dry weight and the content of photosynthetic pigments were analysed. The shoot and root dry weights were determined by drying the samples at $60^{\circ} \mathrm{C}$ in the oven to constant weight.
Determination of the photosynthetic pigments content - The analysis of photosynthetic pigments followed the method described by Munné-Bosch \& Lalueza and (2007). Triplicates of the samples were analyzed in a spectrophotometer. The wavelengths for spectrophotometer reading, as well as the equations used for calculating the content of photosynthetic pigments, were described in Lichtenthaler \& Buschmann (2001) and expressed in milligram of pigment per gram of dry weight ( $\left.\mathrm{mg} \mathrm{g}^{-1} \mathrm{DW}\right)$.

Determination of endogenous ammonium and nitrate content - Aliquots of ca. $100 \mathrm{mg}$ of frozen material obtained from 10 plants were ground to a powder with liquid nitrogen and homogenized with $1,000 \mu \mathrm{L}$ of ultrapure water. Samples were then centrifuged at $22,000 \mathrm{~g}$ and $4{ }^{\circ} \mathrm{C}$ for $10 \mathrm{~min}$, and the supernatants recovered. The endogenous ammonium content was determined with the colorimetric method based on the phenol hypochlorite assay (Weatherburn 1967, MCcullough 1967) and ammonium concentration was expressed as $\mu \mathrm{mol}$ of $\mathrm{NH}_{4}{ }^{+}$produced per gram of dry weight $\left(\mu \mathrm{mol} \mathrm{NH}{ }_{4}^{+}\right.$ $\mathrm{g}^{-1} \mathrm{MS}$ ). The endogenous nitrate content followed the method described by Cataldo et al. (1975) and the nitrate concentration was expressed as $\mu \mathrm{mol}$ of $\mathrm{NO}_{3}{ }^{-}$produced per gram of dry weight ( $\left.\mu \mathrm{mol} \mathrm{NO}{ }_{3}^{-} \mathrm{g}^{-1} \mathrm{DW}\right)$.

Analysis of the NR activity - Nitrate reduction was measured using an in vivo assay (Jaworski 1971 modified by Nievola et al. 2001). Aliquots of ca. $350 \mathrm{mg}$ of fresh material were weighed and incubated in $5 \mathrm{~mL}$ of $0.1 \mathrm{M}$ phosphate buffer (pH 7.5) containing 3\% propanol and $0.1 \mathrm{M} \mathrm{KNO}_{3}$. Tubes containing the samples were vacuum infiltrated three times for $1 \mathrm{~min}$ and incubated in the dark at $30^{\circ} \mathrm{C}$ for 30 min. Aliquots of $1 \mathrm{~mL}$ were taken from the incubating medium at both the beginning and the end of the assay. The nitrite produced was determined by adding $0.3 \mathrm{~mL}$ of $1 \%$ sulphanilamide, which was prepared with $3 \mathrm{M} \mathrm{HCl}$ and 0.3 $\mathrm{mL}$ of $0.2 \% \mathrm{~N}-(1$-naphthyl) ethylene-diamine. All assays were performed in triplicate. Absorbance was read at 540 $\mathrm{nm}$ after $30 \mathrm{~min}$. Nitrate reductase activity was expressed as $\mu \mathrm{mol}$ nitrite produced per hour per gram of dry weight ( $\left.\mu \mathrm{mol} \mathrm{NO}{ }_{2}^{-} h^{-1} \mathrm{~g}^{-1} \mathrm{DW}\right)$.

Extraction and analysis of GS and NADH-GDH activity Aliquots of ca. $250 \mathrm{mg}$ of frozen material obtained from 10 plants were ground to a powder with liquid nitrogen and homogenized with $1.5 \mathrm{~mL}$ of an extraction medium that consisted of $0.05 \mathrm{M}$ imidazole buffer (pH 7.9) and 5 mM DTT. These samples were centrifuged at $21,000 \mathrm{~g}$ and $4{ }^{\circ} \mathrm{C}$ for $60 \mathrm{~min}$, and the supernatant was used to measure the activity of both enzymes. All assays were performed in triplicate.

Analysis of the GS activity - The GS activity was determined based on the in vitro method proposed by Elliott (1955) apud Farnden \& Robertson (1980). The total volume of the enzymatic reaction was $0.5 \mathrm{~mL}$ and consisted of $0.1 \mathrm{M}$ imidazole buffer, $\mathrm{pH}$ 7.5, $49 \mathrm{mM}$ hydroxylamine, $40 \mathrm{mM}$ 
$\mathrm{MgCl}_{2}, 160 \mathrm{mM}$ glutamate, and $35 \mathrm{mM}$ ATP (pH 7.5). The reaction started with the addition of $50 \mu \mathrm{L}$ of the plant extract followed by incubation of the tubes at $35^{\circ} \mathrm{C}$. After $60 \mathrm{~min}$, the reaction was interrupted with the addition of $1 \mathrm{~mL}$ of a solution containing $0.123 \mathrm{M}$ ferric chloride, 0.25 $\mathrm{M} \mathrm{HCl}$, and $0.1225 \mathrm{M}$ trichloroacetic acid. The absorbance was read in a spectrophotometer at $540 \mathrm{~nm}$. The GS activity was expressed in mmol $\mathrm{Y}$-glutamyl-hydroxamate produced per hour per gram of dry weight (mmol لGH h $\mathrm{h} \mathrm{g}^{-1} \mathrm{DW}$ ).

Analysis of the NADH-GDH activity - The method described by Bullen (1956) was used for the determination of the NADH-GDH activity. Firstly, an aliquot of the plant extract was desalted through in the Sephadex PD10/G-25 column (Amersham Pharmacia Biotech) and used in the GDH assay. The NADH-GDH activity was quantified through the amount of NADH consumed in the reaction. The total volume of the reaction was $1 \mathrm{~mL}$ and was composed of $0.1 \mathrm{M}$ Tris buffer (pH 8.2), $13.3 \mathrm{mM}$ 2-oxoglutarate, $0.1 \mathrm{M}\left(\mathrm{NH}_{4}\right)_{2} \mathrm{SO}_{4}$, and $0.16 \mathrm{mM} \mathrm{NADH}$. All reagents were maintained at $30^{\circ} \mathrm{C}$ for 10 minutes before starting the enzymatic reaction. The reaction started with the addition of $0.25 \mathrm{~mL}$ of plant extract and instantly read in a spectrophotometer at $340 \mathrm{~nm}$. The slope was calculated using the linear absorbance range recorded within a period of five minutes. The enzymatic activity was calculated using the molar extinction coefficient ( $\varepsilon$ 340) of $6.22 \times 10^{6} \mathrm{mmol}^{-1} . \mathrm{cm}^{-1}$ and expressed as $\mu \mathrm{mol}$ of NADH consumed per minute per gram of dry weight $\left(\mu \mathrm{mol} \mathrm{NADH} \mathrm{min}^{-1} \cdot \mathrm{g}^{-1} \mathrm{DW}\right)$.

Statistical analyses and experimental design - The experiments followed a completely randomized design in a factorial arrangement $(3 \times 4)$. The experiment had 12 treatments and two harvesting times (seven months of in vitro growth and three months of ex vitro acclimatization) with three independent replicates. For in vitro growth, each experimental unit consisted of three glass flasks with five plants, whereas for the ex vitro acclimatization, each experimental unit had three pots with 10 plants. Data were subjected to a two-way analysis of variance (two-way ANOVA), and the differences among means were compared by Tukey's test $(\mathrm{P}<0.05)$.

\section{Results and Discussion}

Plants cultivated for seven months with $\mathrm{NO}_{3}{ }^{-}$and $\mathrm{NH}_{4} \mathrm{NO}_{3}$ presented $100 \%$ survival with all concentrations used and showed a healthier appearance compared to plants grown with $\mathrm{NH}_{4}^{+}$, which had chlorotic leaves and atrophied appearance (figure 1). In addition, plants cultivated at $15,30,60$, and $90 \mathrm{mM} \mathrm{NH}_{4}^{+}$showed a 55, 56, 57, and $65 \%$ survival, respectively. Furthermore, shoots of plants grown with different $\mathrm{N}$ sources and concentrations showed a biomass decrease when comparing the values of fresh and dry weights (figure $2 \mathrm{a}$ and b). Several studies have described the toxicity of $\mathrm{NH}_{4}^{+}$for most higher plants when supplied as a single N source (Roosta \& Schjoerring 2007, Marschner \& Marschner 2012, Esteban et al. 2016, Ji et al. 2019). However, some aspects of the mechanism of the $\mathrm{NH}_{4}^{+}$toxicity are yet not fully understood (Britto \& Kronzucker 2002, Li et al. 2014). Nevertheless, the tissue toxicity of the $\mathrm{NH}_{4}^{+}$excess can be attributed to uncoupling of photophosphorylation, disturbance in $\mathrm{pH}$ balance ( $\mathrm{Li}$ et al. 2011, Li et al. 2014), high carbon consumption and accumulation of abscisic acid and free putrescine in the plant tissues (Garnica et al. 2010). Furthermore, Andrews et al. (2013) observed that $\mathrm{NO}_{3}^{-}$is required to maintain the biosynthesis and flux of cytokinin at a level enough to mediate normal morphogenesis.

Plants cultivated with $\mathrm{NO}_{3}^{-}$showed the highest means of fresh and dry weights of shoots and roots (figure $2 \mathrm{a}$ and $\mathrm{b}$ ). This increase in dry weight of plants cultivated with $\mathrm{NO}_{3}{ }^{-}$ was also observed for other species, such as Cucumis sativus L. (Roosta \& Schjoerring 2007) and Triticum aestivum L.cv Amarok (Garnica et al. 2010). The $\mathrm{NO}_{3}{ }^{-}$and $\mathrm{NH}_{4}^{+}$ ions are the most available sources of $\mathrm{N}$ for root uptake in most soils, however, the absorption of one particular ion or both of them will depend on the plant species and its physiological characteristics, as well as the ion availability in the soil or substrate (Marschners \& Marschners 2012, Liu \& Wirén 2019). It is well-known that $\mathrm{NO}_{3}^{-}$plays a key role in the cell signalling that activates the gene expression related to uptake, transport and $\mathrm{N}$ assimilation (Crawford 1995, Miller et al. 2007, Krapp 2015), and the cytokinin synthesis, which is responsible for regulating cell growth (division and multiplication) and development (expansion) in higher plants (Garnica et al. 2010, Andrews et al. 2013, Buchanan et al. 2015). This could be the reason why we found a greater accumulation of biomass in plants grown with NO3-

With regard to the dry and fresh weight of roots, the lowest values were also obtained for plants grown with $\mathrm{NH}_{4}^{+}$(figure $2 \mathrm{c}$ and d). This reduction can be attributed to several biochemical and physiological factors previously mentioned for shoots, but which could also affect roots. In addition, Barth et al. (2010) reported that $\mathrm{NH}_{4}^{+}$inhibit the activity of the enzymes GDP-mannose pyrophosphorylase and GDP-mannose, which are required for the biosynthesis of L-ascorbic acid and $\mathrm{N}$ glycoproteins. Failure in the $\mathrm{N}$-glycosylation process causes membrane and cell wall deformations, compromising the cell cycle and leading to cell death, consequently inhibiting root growth (Qin et al. 2008, Kempinski et al. 2013). Furthermore, it has been observed that the $\mathrm{NH}_{4}^{+}$excess decreases root gravitropism in Arabidopsis sp. by the redistribution of auxin, which implies a decrease in the root length (Zou et al. 2012). Thus, this disturbance negatively influenced root growth in plants cultivated with $\mathrm{NH}_{4}^{+}$.

Moreover, both root fresh and dry weights gradually increased in plants cultivated with 15,30 , and $60 \mathrm{mM}$ of $\mathrm{N}$ as $\mathrm{NO}_{3}{ }^{-}$compared to the other two nitrogen sources (figure 


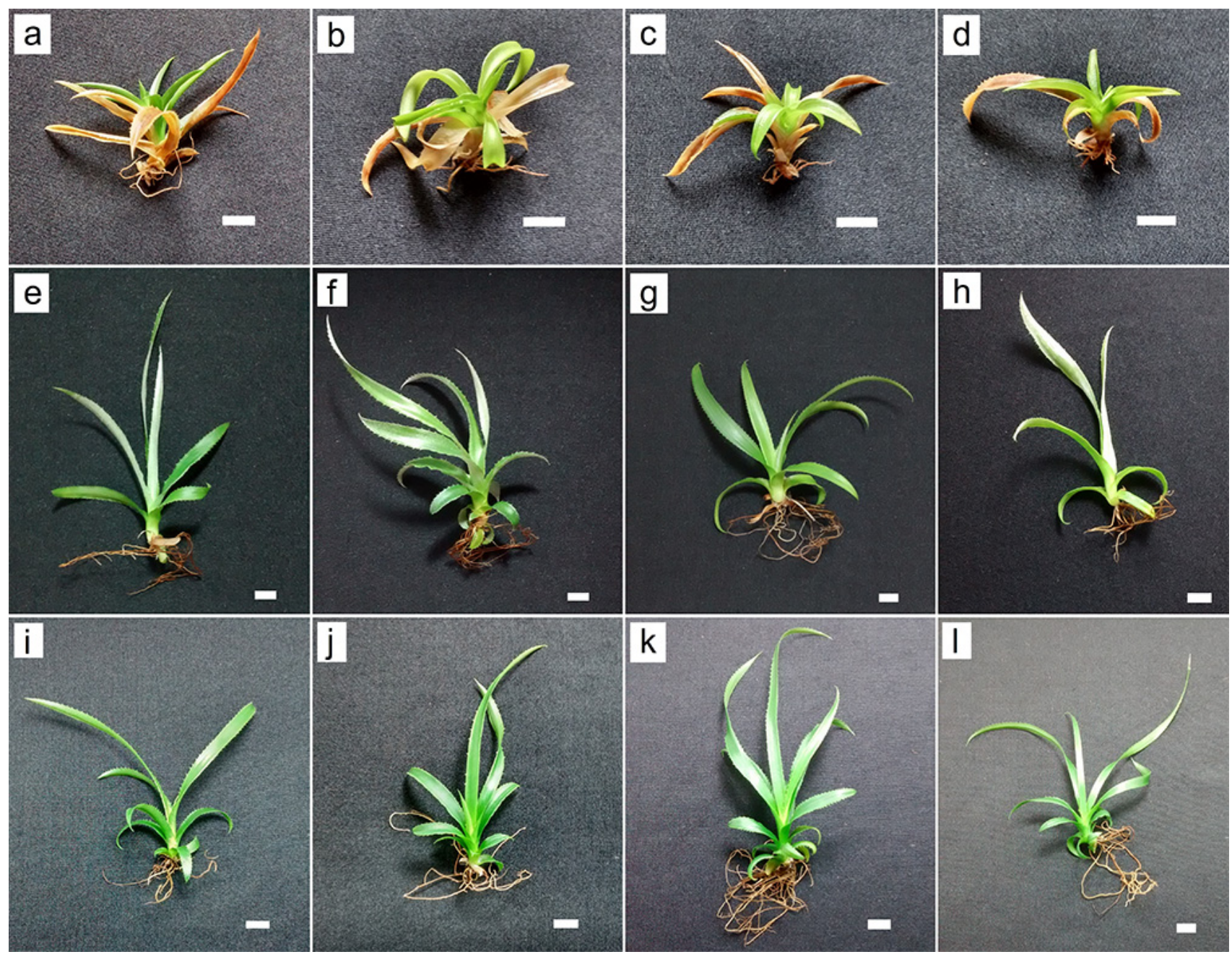

Figure 1. General view of Ananas comosus var. ananassoides (Baker) Coppens \& F.Leal cultivated in vitro with MS-1962 modified medium with different sources $\left(\mathrm{NH}_{4}{ }^{+}, \mathrm{NO}_{3}{ }^{-}\right.$, and $\left.\mathrm{NH}_{4} \mathrm{NO}_{3}\right)$ and $\mathrm{N}$ concentrations $(15,30,60$, and $90 \mathrm{mM})$ for seven months. a-d. Plants grown with $15 \mathrm{mM}, 30 \mathrm{mM}, 60 \mathrm{mM}$, and $90 \mathrm{mM}$ of $\mathrm{N}$ as $\mathrm{NH}_{4}^{+}$, respectively. e-h. Plants grown with $15 \mathrm{mM}, 30 \mathrm{mM}, 60 \mathrm{mM}$, and 90 $\mathrm{mM}$ of $\mathrm{N}_{\text {as }} \mathrm{NO}_{3}{ }^{-}$, respectively. i-1. Plants grown with $15 \mathrm{mM}, 30 \mathrm{mM}, 60 \mathrm{mM}$, and $90 \mathrm{mM}$ of N as $\mathrm{NH}_{4} \mathrm{NO}_{3}$, respectively. Bars $=1 \mathrm{~cm}$. Photos from Priscila P. A. Silva.

$2 \mathrm{c}$ and d). As previously mentioned, $\mathrm{NO}_{3}{ }^{-}$is a signalling molecule for several cell functions, including cytokinin biosynthesis (Garnica et al. 2010, Andrews et al. 2013). Some authors have observed that the cytokinin regulates auxin distribution in the root apical meristem and promotes cell division in the quiescent centre of the root apical meristem, which is usually mitotically inactive (Ruzicka et al. 2009, Zhang et al. 2011, Zhang et al. 2013). This increase in cell division induced by the cytokinin might explain the increase in root biomass in plants grown with $\mathrm{NO}_{3}^{-}$.

With regard to the photosynthetic pigments in plants cultivated in vitro, the highest values were obtained in plants grown at all $\mathrm{NH}_{4} \mathrm{NO}_{3}$ concentrations, with the highest mean achieved in those grown with $60 \mathrm{mM}$ of $\mathrm{N}$ as $\mathrm{NH}_{4} \mathrm{NO}_{3}$ (figure 3). The content of chlorophyll $a$ was more than twice of the chlorophyll $b$ content and three times higher than of carotenoids (figure 3). This increase in photosynthetic pigments and the same differences in the quantities of each pigment were observed for the bromeliad Alcantarea imperialis (Carrière) Harms cultivated with the same N sources and concentrations (Kurita 2015). Studies have reported that plants supplemented with non-toxic concentrations of $\mathrm{NH}_{4}^{+}$present higher chlorophyll content per leaf unit area (Raab \& Tarry 1994, Claussen \& Lenz 1999). This explains the higher amount of pigments in plants grown with different $\mathrm{NH}_{4} \mathrm{NO}_{3}$ concentrations, compared to plants cultivated with $\mathrm{NO}_{3}{ }^{-}$concentrations. However, there are no published studies that clarify this increase in photosynthetic pigments associated with the supplementation of different sources of inorganic N. According to Raab $\&$ Tarry (1994), the carbohydrate requirement for $\mathrm{NH}_{4}^{+}$ assimilation might influence the $\mathrm{NH}_{4}^{+}$toxicity in plants, since the faster the $\mathrm{NH}_{4}^{+}$absorbed is assimilated, the less is the damage caused by toxicity. Therefore, the increase 


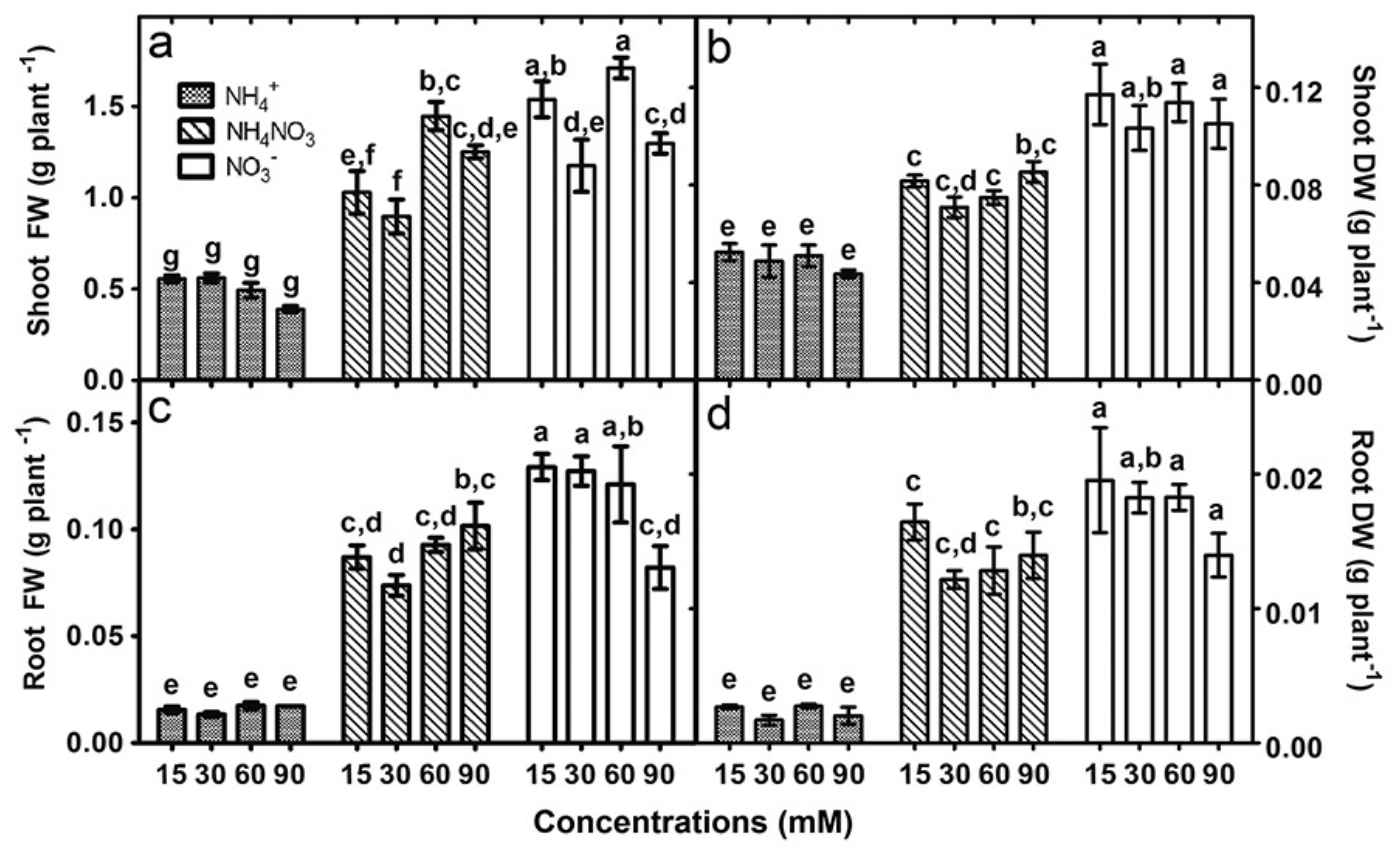

Figure 2. Fresh (FW) and dry weight (DW) of shoot and root of Ananas comosus var. ananassoides (Baker) Coppens \& F.Leal cultured in vitro for seven months with $15,30,60$, and $90 \mathrm{mM}$ of $\mathrm{N}$ in the forms of $\mathrm{NH}_{4}^{+}, \mathrm{NO}_{3}^{-}$or $\mathrm{NH}_{4} \mathrm{NO}_{3}$. Different letters indicate significant statistical differences $(p \leq 0.05)$

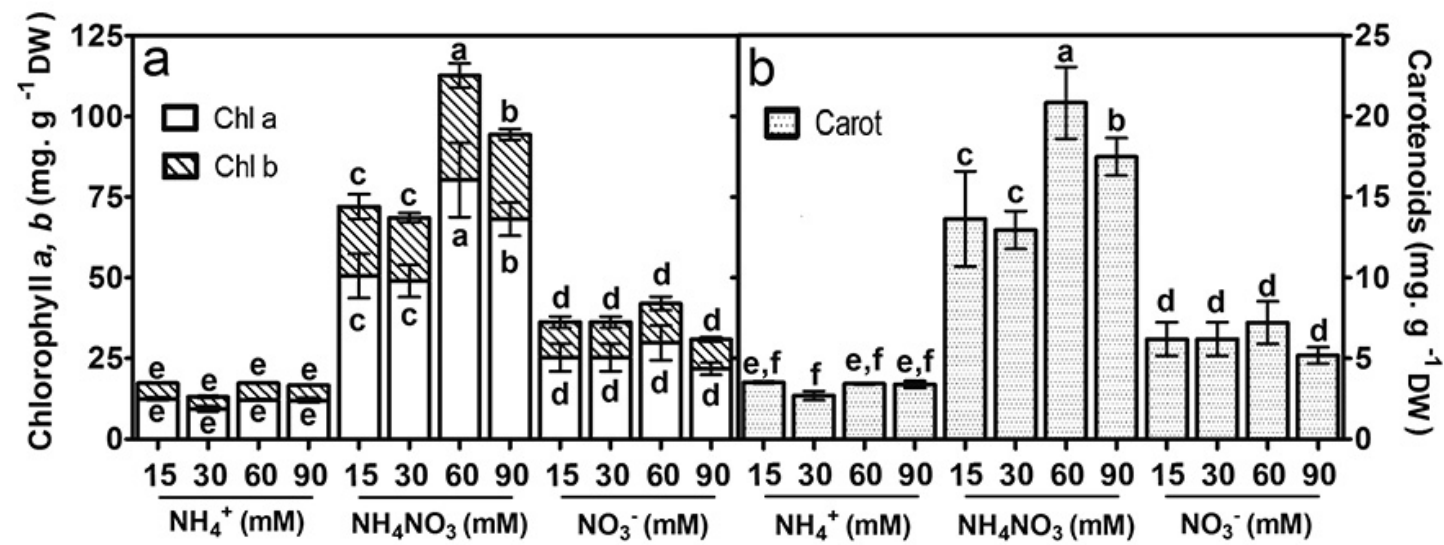

Figure 3. Photosynthetic pigments content in leaves of Ananas comosus var. ananassoides (Baker) Coppens \& F.Leal cultured in vitro for seven months with $15,30,60$, and $90 \mathrm{mM}$ of $\mathrm{N}$ in the forms of $\mathrm{NH}_{4}^{+}, \mathrm{NO}_{3}{ }^{-}$or $\mathrm{NH}_{4} \mathrm{NO}_{3}$. a. Chlorophyll $a$ and $b$. b. Carotenoids. Different letters indicate significant statistical differences $(p \leq 0.05)$.

in photosynthetic pigments in plants of $A$. comosus var. ananassoides grown with different $\mathrm{NH}_{4} \mathrm{NO}_{3}$ concentrations seems to be related to the need for a supply of carbon skeletons for the assimilation of the $\mathrm{NH}_{4}^{+}$absorbed in the roots.

With regard to nitrogen assimilation, both NR activity (NR) and endogenous $\mathrm{NO}_{3}{ }^{-}$content (ENC) were below the detection levels of the method in plants grown with different $\mathrm{NH}_{4}{ }^{+}$concentrations, and therefore, it was not possible to quantify them. In these treatments, little growth was observed.

With regard to the NR activity, the highest means were obtained in plants cultivated with $90 \mathrm{mM}$ of $\mathrm{N}$ as $\mathrm{NH}_{4} \mathrm{NO}_{3}$ compared to those cultivated with the same concentrations of $\mathrm{NO}_{3}{ }^{-}$(figure $4 \mathrm{a}$ ), which might be related to higher ENC in plants grown with $90 \mathrm{mM}$ of $\mathrm{N}^{2} \mathrm{NO}_{3}^{-}$(figure $4 \mathrm{~b}$ ). This is because in angiosperms, the $\mathrm{NO}_{3}{ }_{3}^{-}$absorbed can be either reduced immediately in the roots or transported via the xylem to the shoot, where it is stored in the vacuoles for later reduction according to the plant necessity (Cárdenas-Navarro et al. 1999, Krapp 2015). The $\mathrm{NO}_{3}{ }^{-}$stored is important for the cellular osmotic balance, besides being a nitrogen reserve source for N-shortage periods (Chen et al. 2004, Miller et al. 2007, Krapp 2015).

As shown in figure $5 \mathrm{a}$, plants cultivated with $15,30,60$, and $90 \mathrm{mM}$ of $\mathrm{N}$ as $\mathrm{NH}_{4} \mathrm{NO}_{3}$ showed the highest glutamine 


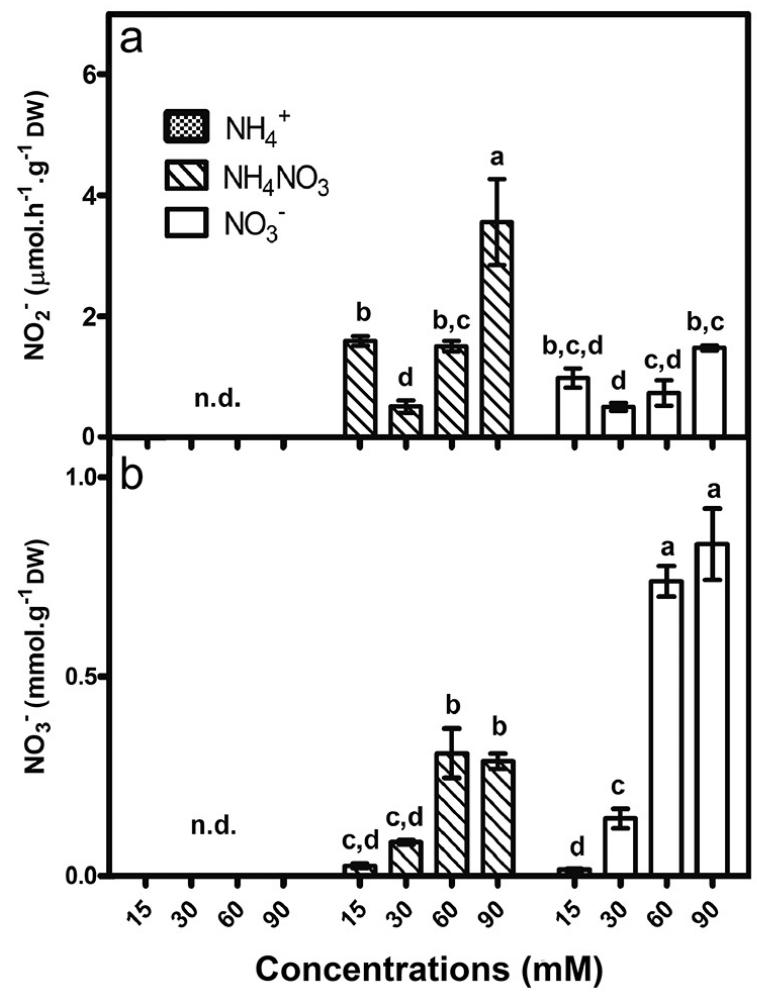

Figure 4. Nitrate reductase activity (a) and endogenous $\mathrm{NO}_{3}^{-}$ content (b) in leaves of Ananas comosus var. ananassoides (Baker) Coppens \& F.Leal cultured in vitro for seven months with 15, 30,60 , and $90 \mathrm{mM}$ of $\mathrm{N}$ in the forms of $\mathrm{NH}_{4}^{+}, \mathrm{NO}_{3}^{-}$or $\mathrm{NH}_{4} \mathrm{NO}_{3}$. Different letters indicate significant statistical differences $(p \leq 0.05)$.

synthetase activity (GS) when compared to plants grown with the other two nitrogen sources $\left(\mathrm{NH}_{4}^{+}\right.$and $\left.\mathrm{NO}_{3}^{-}\right)$. Some studies have reported that GS is not affected by different $\mathrm{N}$ supplies in Solanum lycopersicum L. and Zea mays L. (Magalhães \& Huber 1991), Vaccinium corymbosum L., Rubus idaeus L., and Fragaria ananassa Duch. (Claussen \& Lenz 1999). However, plants of Catasetum fimbriatum (Morren) Lindl. (Majerowicz et al. 2000) and Solanum lycopersicum L. cv. Rio Grande (Horchani et al. 2010) grown with $\mathrm{NH}_{4} \mathrm{NO}_{3}$ or $\mathrm{NH}_{4}^{+}$showed a higher GS activity than those grown with $\mathrm{NO}_{3}^{-}$. Therefore, the GS response to the nitrogen source provided seems to vary according to the plant species.

The $\mathrm{NH}_{4}^{+}$assimilation into glutamine and glutamate performed by the enzymes glutamine synthetase (GS) and glutamine oxoglutarate aminotransferase (GOGAT) is considered the main pathway of $\mathrm{N}$ assimilation (Miflin \& Habash 2002, Bernard \& Habash 2009, Rennenberg et al. 2010, Xu et al. 2012, Krapp 2015), and $\mathrm{NH}_{4}^{+}$detoxification under normal conditions of plant growth. Thus, the higher GS activity observed in A. comosus var. ananassoides cultivated with $\mathrm{NH}_{4} \mathrm{NO}_{3}$ might be a mechanism to avoid the toxicity of the $\mathrm{NH}_{4}^{+}$absorbed.

The lower GS activity in plants grown with different $\mathrm{NH}_{4}^{+}$concentrations (figure $5 \mathrm{a}$ ), associated with the other parameters previously analysed (fresh and dry weights, and

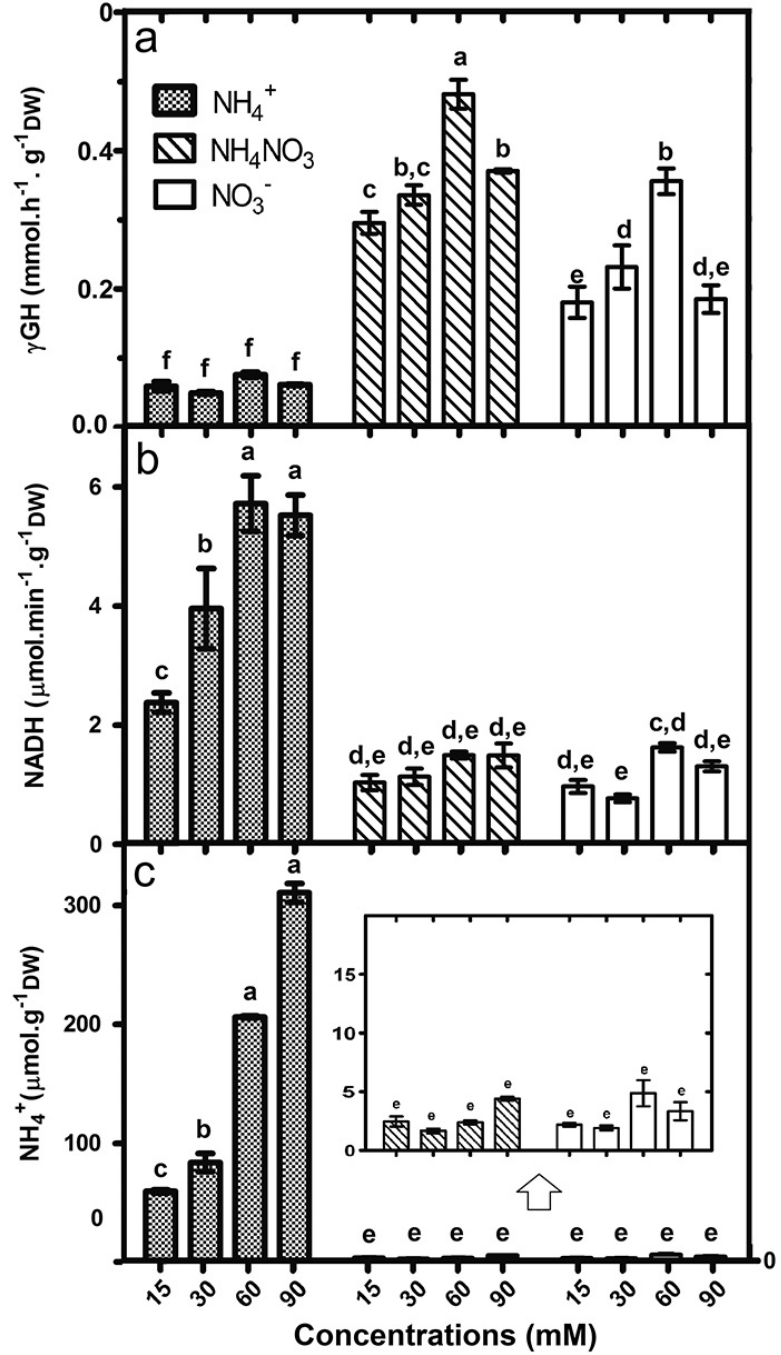

Figure 5. Glutamine synthetase activity (a), glutamate dehydrogenase activity (b) and endogenous $\mathrm{NH}_{4}^{+}$content (c) in leaves of Ananas comosus var. ananassoides (Baker) Coppens \& F.Leal cultured in vitro for seven months with 15, 30, 60, and 90 $\mathrm{mM}$ of $\mathrm{N}$ in the forms of $\mathrm{NH}_{4}^{+}, \mathrm{NO}_{3}{ }^{-}$or $\mathrm{NH}_{4} \mathrm{NO}_{3}$. Different letters indicate significant statistical differences $(p \leq 0.05)$.

content of photosynthetic pigments) and the appearance of the plants, indicated that they were going through the senescence process. Some authors have verified that during the senescence process, leaves show low GS activity (Peeters \& Van Laere 1992, Chen et al. 1997) due to the high degradation of proteins such as ribulose-1,5-bisphosphate carboxylase oxygenase (RuBisCo), plastid GS and plastid GOGAT in the chloroplast stroma (Palatnik et al. 1999, Parry et al. 2003, Kato et al. 2005, Masclaux-Daubresse et al. 2010).

In addition, plants cultivated with $\mathrm{NH}_{4}^{+}$had the highest glutamate dehydrogenase activity (GDH) and endogenous $\mathrm{NH}_{4}^{+}$content (EAC) (figure $5 \mathrm{~b}$ and c). The $\mathrm{NH}_{4}^{+}$accumulation is due to the high proteolysis that occurs during the senescence process, which releases large amounts of amino acids that are catabolized by GDH and 
asparaginases (Bernad \& Habash 2009). The GDH can catalyse both the amination of 2-oxoglutarate (2-OG) and deamination of glutamate (Glu) (Lea \& Miflin 2003, Forde $\&$ Lea 2007). These processes occur as a deviation to ensure that $\mathrm{N}$-assimilation does not excessively decrease the 2-OG amount in the mitochondria since this is an intermediate in the tricarboxylic acid cycle (Robison et al. 1991, Miflin \& Habash 2002, Lea \& Miflin 2003). Therefore, the higher GDH in plants of A. comosus var. ananassoides cultivated with $\mathrm{NH}_{4}^{+}$can be related to the Glu catabolism to generate both 2-OG for the tricarboxylic acid cycle and NADH for other metabolic cell processes.

Three months after being transferred to ex vitro conditions, plants acclimatized with different $\mathrm{NO}_{3}{ }^{-}$and $\mathrm{NH}_{4} \mathrm{NO}_{3}$ concentrations showed no mortality and presented a healthy appearance in all concentrations used. On the contrary, plants grown with different $\mathrm{NH}_{4}^{+}$concentrations had $100 \%$ mortality. Changes in some factors, such as increases in transpiration rate and luminosity, replacement of a heterotrophic condition to autotrophic condition, among others, during the transition from in vitro culture to ex vitro conditions, might be limiting for the propagation of some species (Grattapaglia \& Machado 1998, Hartmann et al. 2002, Bregonci et al. 2008, Berilli et al. 2011). Consequently, changes in these factors might have induced the death of the plants cultivated in vitro with $\mathrm{NH}_{4}^{+}$.

Plants grown ex vitro with 30,60 , and $90 \mathrm{mM}$ of $\mathrm{N}$ as $\mathrm{NH}_{4} \mathrm{NO}_{3}$ showed higher means in the fresh and dry weights of the shoots compared to the other treatments (figure 6 $\mathrm{a}$ and $\mathrm{b}$ ). Up to date, there are no published studies that evaluate the acclimatization of plants cultivated in vitro with different $\mathrm{N}$ sources and concentrations. Nevertheless, Kurita (2015) verified that the bromeliad A. imperialis cultivated under controlled environmental conditions showed higher growth when cultivated with $\mathrm{NO}_{3}{ }^{-}$than when fertilized with $\mathrm{NH}_{4}^{+}$or $\mathrm{NH}_{4} \mathrm{NO}_{3}$. In the present study, opposite results were obtained for $A$. comosus var. ananassoides. In the case of roots, both the fresh and dry weights increased with $15 \mathrm{mM}$ of $\mathrm{N}^{2} \mathrm{NO}_{3}^{-}$(figure $6 \mathrm{c}$ and d). Kiba et al. (2011) observed that high N supplementation suppressed root growth in most plants, while $\mathrm{N}$ limitation accelerated their growth. This modulation in the root growth related to low or high $\mathrm{N}$ availability is mediated mainly by the signalling of the phytohormones auxin and abscisic acid (Kiba et al. 2011, Vidal et al. 2013). Some studies have shown that a decrease in $\mathrm{N}$ availability might promote auxin accumulation in the roots and, consequently, lead to root elongation (Walch-Liu et al. 2006, Tamaki \& Mercier 2007, Tian et al. 2008). Furthermore, it was observed that auxins were also responsible for the induction of the lateral root development in response to low $\mathrm{N}$ supplementation (Fukaki \& Tasaka 2009, Ma et al. 2014).

The content of photosynthetic pigments in plants acclimatized ex vitro was the highest when cultivated with different $\mathrm{NH}_{4} \mathrm{NO}_{3}$ concentrations, with the highest mean in those plants grown with $60 \mathrm{mM}$ of $\mathrm{N}$ as $\mathrm{NH}_{4} \mathrm{NO}_{3}$ (figure 7 $a$ and $b$ ). In all treatments, the content of chlorophyll $a$ was more than twice the content of chlorophyll $b$ and three times greater than the carotenoid content (figure 7), showing a similar tendency to plants grown in vitro.

Both in vitro and ex vitro results indicated that the cultivation of $A$. comosus var. ananassoides with $\mathrm{NH}_{4}^{+}$ as the only $\mathrm{N}$ source is not feasible. Our results indicated that the growth of plants with $\mathrm{NO}_{3}{ }^{-}$as the only $\mathrm{N}$ source is possible, but it is not favourable for photosynthetic pigments.

In addition, the enzymes NR and GS assimilated less $\mathrm{N}$ as $\mathrm{NO}_{3}{ }^{-}$than as $\mathrm{NH}_{4} \mathrm{NO}_{3}$. Therefore, the use of $\mathrm{NH}_{4} \mathrm{NO}_{3}$ for both in vitro and ex vitro cultivation seems to be the best option,

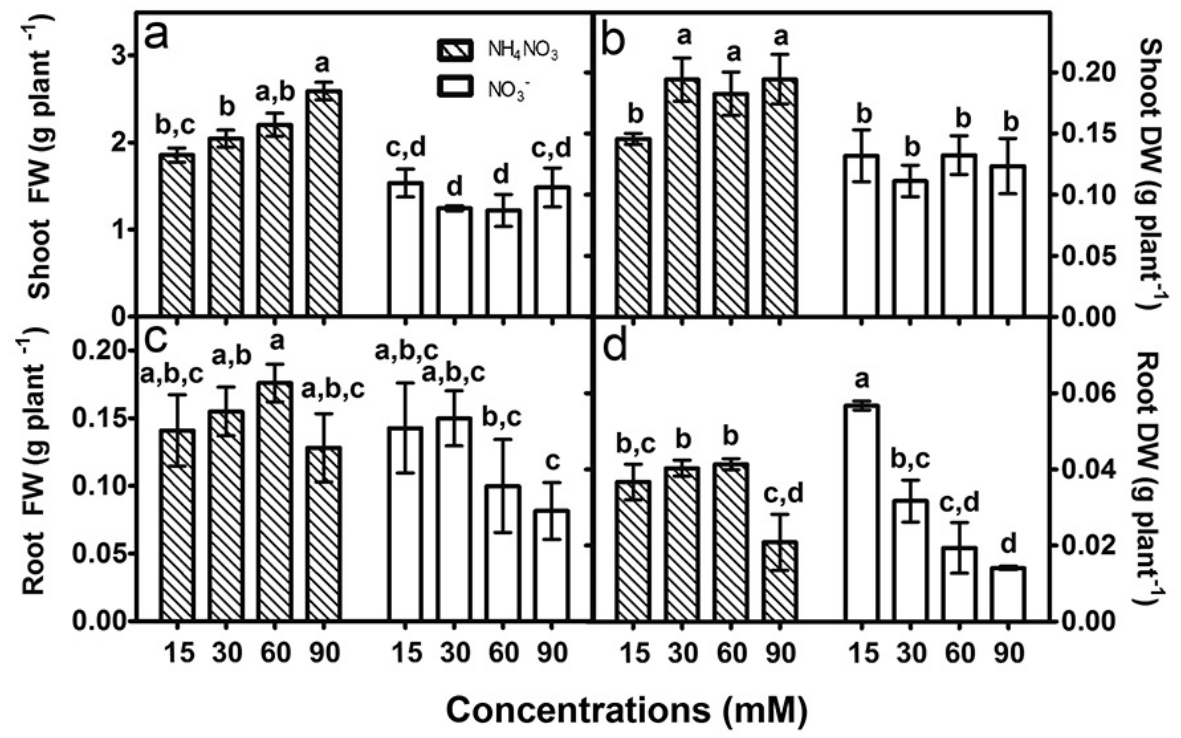

Figure 6. Fresh (FW) and dry weight (DW) of shoot and root of Ananas comosus var. ananassoides (Baker) Coppens \& F.Leal ex vitro acclimatized for three months with 15,30,60, and $90 \mathrm{mM}$ of $\mathrm{N}$ in the forms of $\mathrm{NH}_{4}^{+}, \mathrm{NO}_{3}^{-}$or $\mathrm{NH}_{4} \mathrm{NO}_{3}$. Different letters indicate significant statistical differences $(p \leq 0.05)$. 
since plants presented higher amounts of photosynthetic pigments in all analysed concentrations, higher biomass in both in vitro and ex vitro cultivation, and higher $\mathrm{N}$ uptake in vitro. In general, $60 \mathrm{mM}$ of $\mathrm{N}$ as $\mathrm{NH}_{4} \mathrm{NO}_{3}$ seems to be the best $\mathrm{NH}_{4} \mathrm{NO}_{3}$ concentration, since it leads to the highest content of photosynthetic pigments in both in vitro and ex vitro cultivated plants. Furthermore, plants grown with this concentration showed higher biomass and GS activity, and assimilated more $\mathrm{N}$ than plants cultivated with the other $\mathrm{NH}_{4} \mathrm{NO}_{3}$ concentrations.

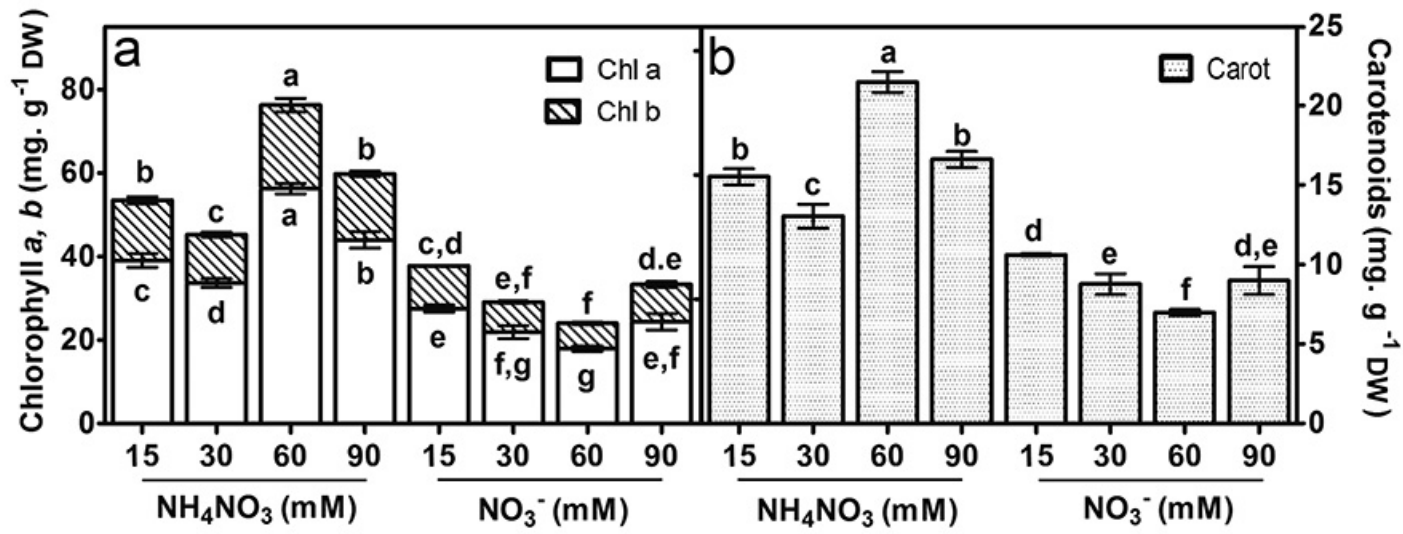

Figure 7. Photosynthetic pigments content in leaves of Ananas comosus var. ananassoides (Baker) Coppens \& F.Leal cultured ex vitro for seven months with 15,30,60, and $90 \mathrm{mM}$ of $\mathrm{N}$ in the forms of $\mathrm{NH}_{4}^{+}, \mathrm{NO}_{3}^{-}$or $\mathrm{NH}_{4} \mathrm{NO}_{3}$. (A) Chlorophyll $a$ and $b$; (B) Carotenoids. Different letters indicate significant statistical differences $(p \leq 0.05)$

\section{Conclusion}

Our study showed that plants of $A$. comosus var. ananassoides are not able to grow with $\mathrm{NH}_{4}^{+}$as the sole source of $\mathrm{N}$ and that it is recommended to use $60 \mathrm{mM}$ of $\mathrm{N}$ as $\mathrm{NH}_{4} \mathrm{NO}_{3}$ for both in vitro and ex vitro cultivation of this bromeliad.

\section{Acknowledgments}

This work is part of the Masters' Dissertation of the first Author, carried out at Instituto de Botânica, São Paulo, SP, Brazil and had financial support from Conselho Nacional de Desenvolvimento Científico e Tecnológico (CNPq).

\section{Literature cited}

Andrade, S.V. \& Tamaki, V. 2016. In vitro growth of Nidularium Minutum Mez ( Bromeliaceae ) in different concentrations of nitrogen, phosphorus, potassium and calcium. Journal of Plant Nutrition 39(11): 1634-1643.

Andrews, M., Raven, J.A. \& Lea, P.J. 2013. Do plants need nitrate? The mechanisms by which nitrogen form affects plants. Annals of Applied Biology 163(2): 1-26.

Albert, L.H.B. 2004. Aspectos morfoanatômicos de mudas de abacaxizeiro 'Smooth Cayenne' micropropagadas. Tese Doutorado, Universidade Federal de Lavras, Lavras.

Aranda-Peres, A.N., Peres, L.E.P., Higashi, E.N. \& Martinelli, A.P. 2009. Adjustment of mineral elements in the culture medium for the micropropagation of three Vriesea bromeliads from the brazilian atlantic forest: the importance of calcium. Hortscience 44: 106-112.
Araújo, N.A.B.de, Kurita, F.M.K. \& Tamaki, V. 2012. Nutritional reserves in seeds of bromeliad species. Communications in Plant Sciences 2(3-4): 57-59.

Barth, C., Gouzd, Z.A., Steelt, H.P. \& Imperio, R.M. 2010. A mutation in GDP-mannose pyrophosphorylase causes conditional hypersen- sitivity to ammonium, resulting in Arabidopsis root growth inhibition, altered ammonium metabolism, and hormone homeo- stasis. Journal of Experimental Botany 61: 379-394.

Bullen, W.A. 1956. The isolation and characterization of glutamic dehydrogenase from corn leaves. Archives Biochemistry and Biophysics 62: 173-183.

Berilli, S.S., Carvalho, A.J.C., Freitas, S.J., Faria, D.C. \& Marinho., C.S. 2011. Avaliação do desenvolvimento de diferentes tamanhos de mudas micropropagadas de abacaxizeiro, após aclimatação. Revista Brasileira de Fruticultura 33(1): 208-214.

Bernard, S.M. \& Habash, D.Z. 2009. The importance of cytosolic glutamine synthetase in nitrogen assimilation and recycling. New Phytologist 182: 608-620.

Braun, H., Coelho, S.F., Silva, M.C.C., Fontes, P.C.R., Cecon, P.R. \& Busato, C. 2013. Absorção, metabolismo e diagnóstico do estado de nitrogênio em plantas de batata. Revista de Ciências Agrárias 56(3): 185-195.

Bregonci, S.I.; Reis, E.S., Almeida, G.D., Brum, V.J. \& Zucoloto, M. 2008. Avaliação do crescimento foliar e radicular de mudas micropropagadas do abacaxizeiro cv. gold em aclimatação. Idesia 26(3): 87-96.

Britto, D.T. \& Kronzucker, H.J. 2002. $\mathrm{NH}_{4}^{+}$toxicity in higher plants: a critical review. Journal of Plant Physiology 159: 567-584. 
Buchanan, B.B., Gruissem, W. \& Jones, R.L. 2015. Biochemistry and Molecular Biology of Plants. $2^{\text {nd }}$ ed. John Wiley \& Sons, West Sussex/UK.

Bunn, E., Turner, S.R. \& Dixon, K. 2011. Biotechnology for saving rare and threatened florain a biodiversity hotspot. In Vitro Cellular \& Developmental Biology Plant 47(1): 188-200.

Calvete, E.O., Azevedo, M., Bordignon, M.H. \& Suzin, M. 2002. Análises anatômicas e da biomassa em plantas de morangueiro cultivadas in vitro e ex vitro. Horticultura Brasileira 20(4): 649-653.

Cárdenas-Navarro, R., Adamowicz, S. \& Robin, P. 1999. Nitrate accumulation in plants: a role for water. Journal of Experimental Botany 50: 613-624.

Carvalho, A.C.P.P.de, Pinheiro, M.V.M., Dias, G.deM.G. \& Morais, J.P.S. 2012. Estiolamento in vitro de plantas: alternativa para a produção de mudas micropropagadas de abacaxizeiro ornamental. Embrapa Agroindústria Tropical, Circular Técnica 42: 1-12.

Cataldo, D.A., Maroon, M., Schrader, L.E. \& Youngs, V.L. 1975. Rapid colorimetric determination of nitrate in plant tissue by nitration of salicylic acid. Communications in Soil Science and Plant Analysis 6(1): 71-80.

Chen, S., Hung, K. \& Kao, C. 1997. Ammonium accumulation is associated with senescence of rice leaves. Plant Growth Regulation 21: 195-201.

Chen, B.M., Wang, Z.H., Li, S.X., Wang, G.X., Song, H.X. \& Wang, X.N. 2004. Effects of nitrate supply on plant growth, nitrate accumulation, metabolic nitrate concentration and nitrate reductase activity in three leafy vegetables. Plant Science 167: 635-643.

Claussen, W. \& Lenz, F. 1999. Effect of ammonium or nitrate nutrition on net photosynthesis, growth, and activity of the enzymes nitrate reductase and glutamine synthetase in blueberry, raspberry and strawberry. Plant Soil 208(1) 95-102.

Crawford, N. 1995. Nitrate: nutrient and signal for plant growth. The Plant Cell 7: 859-868.

Dias, G.deM.G., Carvalho, A.C.P.P.de, Pinheiro, M.V.M. \& Morais, J.P.S. 2008. Micropropagação de abacaxi ornamental (Ananas comosus var. ananassoides) por estiolamento e regeneração de plântulas. Plant Cell Culture \& Micropropagation 4(1): 1-7.

Dias, M.M., Pasqual M., Araújo, A.G., Santos, V.A.dos, Custódio T.N. \& Costa, F.H.S.da. 2010. Enraizamento ex vitro e aclimatização de plantas micropropagadas de abacaxizeiro ornamental. Tecnologia \& Ciência Agropecuária 4(2): 29-33.

Dias, M.M., Pasqual, M., Araújo, A.G.de \& Santos, V.A. 2011a. Reguladores de crescimento na propagação in vitro de abacaxizeiro ornamental. Revista Brasileira de Ciências Agrárias 6(3): 383-390.

Dias, M.M., Pasqual, M., Araújo, A.G.de, Santos, V.A.dos, Oliveira, A.C.de \& Rodrigues, V.A. 2011 b. Concentrações de reguladores vegetais no estiolamento in vitro de ananás do campo. Semina: Ciências Agrárias 32(2): 513-520.
Dias, M.M., Nietsche, S. \& Pereira, M.C.T. 2013. Concentrações de NPK no cultivo in vitro de abacaxizeiro ornamental. Tecnologia \& Ciência Agropecuária 7(4): 1-6.

Endres, L. \& Mercier, H. 2001. Ammonium and urea as nitrogen sources for bromeliads. Journal of Plant Physiology 158: 205-212.

Epstein, E. \& Bloom, A.J. 2006. Nutrição mineral de plantas: princípios e perpectivas. 2 ed. Trad. Editora Planta, Londrina.

Esteban, R., Ariz, I., Cruz, C. \& Moran, J.F. 2016. Review: Mechanisms of ammonium toxicity and the quest for tolerance. Plant Science 248: 92-101.

Farnden, K.J.S. \& Robertson, J.G. 1980. Methods for studying enzyme involved in metabolism related to nitrogenase. In: F.J. Bergsen (ed.). Methods for evaluating biological nitrogen fixation. Jonh Wiley \& Sons, West Sussex/UK, pp. 279-286.

Forde, B.G. \& Lea, P.J. 2007. Glutamate in plants: metabolism, regulation and signalling. Journal of Experimental Botany 58: 2339-2358.

Fukaki, H. \& Tasaka, M. 2009. Hormone interactions during lateral root formation. Plant Molecular Biology 69: 437-449.

Garnica, M., Houdusse, F., Zamarreno, A.M. \& GarciaMina, J.M. 2010. The signal effect of nitrate supply enhances active forms of cytokinins and indole acetic content and reduces abscisic acid in wheat plants grown with ammonium. Journal of Plant Physiology 167: 12641272.

Grattapaglia, D. \& Machado, M.A. 1998. Micropropagação. In: A.C. Torres, L.S. Caldas \& J.A. Buso (eds.). Cultura de tecidos e transformação genética de plantas. 1 ed. Embrapa- CNPH, Brasília, pp.183-260.

Hachiya, T. \& Sakakibara, H. 2017. Interactions between nitrate and ammonium in their uptake, allocation, assimilation, and signaling in plants. Journal of Experimental Botany 68(10): 2501-2512.

Hartmann, H.T., Kester, D.E., Davis Júnior, F.T. \& Geneve, R.L. 2002. Plant propagation: principles and practices. Englewood Clipps, New York.

Horchani, F., Aschi-Smiti, S. \& Brouquisse, R. 2010. Involvement of nitrate reductase in the tolerance of tomato (Solanum lycopersicum L.) plants to prolonged root hypoxia. Acta Physiologiae Plantarum 32: 11131123.

Jaworski, E. 1971. Nitrate reductase assay in intact plant tissues. Biochemical and Biophysical Research Communications 43(6): 1274-1279.

Ji, Y., Li, Q., Liu, G., Selvaraj, G., Zheng, Z., Zou, J. \& Wei, Y. 2019. Roles of cytosolic glutamine synthetases in Arabidopsis development and stress responses. Plant and Cell Physiology 60: 657-671.

Kato, Y., Yamamoto, Y., Murakami, S. \& Sato, F. 2005. Post-translational regulation of CND41 protease activity in senescent tobacco leaves. Planta 222: 643-651. 
Kempinski, C.F., Crowell, S.V., Smeeth, C. \& Barth, C. 2013. The novel Arabidopsis thaliana svt2 suppressor of the ascorbic acid-deficient mutant vtc1-1 exhibits phenotypic and genotypic instability. F1000 Research 1: 2-6.

Kiba, T., Kudo, T., Kojima, M. \& Sakakibara, H. 2011. Hormonal control of nitrogen acquisition: roles of auxin, abscisic acid, and cytokinin. Journal of Experimental Botany 62:1399-1409.

Kurita, F.M.K. 2015. Assimilation of different nitrogen sources in the induction of the mutiplication of bromeliad Alcantarea imperialis (Carrière) Harms cultivated in vitro. Thesis from Instituto de Botânica, São Paulo, Brazil.

Kraiser, T., Gras, D.E., Gutierrez, A.G., Gonzalez, B. \& Gutierrez, R.A. 2011. A holistic view of nitrogen acquisition in plants. Journal of Experimental Botany 62: 1455-1466.

Krapp, A. 2015. Plant nitrogen assimilation and its regulation: a complex puzzle with missing pieces. Current Opinion in Plant Biology 25: 115-122.

Lea, P.J. \& Miflin, B.J. 2003. Glutamate synthase and the synthesis of glutamate in plants. Plant Physiology and Biochemistry 41: 555-564.

Li, B., Li, G., Kronzucker, H.J., Balusca, F. \& Shi, W. 2014. Ammonium stress in Arabidopsis: Signaling, genetic loci, and physiological targets. Trends in Plant Science 19(2): 107-114.

Li, B., Shi, W. \& Su, Y. 2011. The differing responses of two Arabidopsis ecotypes to ammonium are modulated by the photoperiod regime. Acta Physiologiae Plantarum 33: 325-334.

Lichtenthaler, H.K. \& Buschmann, C. 2001. Chlorophylls and carotenoids: measurement and characterization by UV-VIS. Current Protocols in Food Analytical Chemistry F4.3.1-F4. 1-8.

Lima, A.P.P.S., Brito, A.L. \& Santana, J.R.F. 2020. Micropropagation of Chapada Diamantina ornamental bromeliad. Ciência Rural 50(2): e20180922.

Liu, Y. \& Wirén, N.von. 2017. Ammonium as a signal for physiological and morphological responses in plants. Journal of Experimental Botany 68: 2581-2592.

Luo, J., Zhou, J., Li, H., Shi, W., Polle, A., Lu, M., Sun, X. \& Luo, Z.B. 2015. Global poplar root and leaf transcriptomes reveal links between growth and stress responses under nitrogen starvation and excess. Tree Physiology 35: 1283-1302.

Magalhães, J.R. \& Huber, D.M. 1991. Response of ammonium assimilation enzymes to nitrogen form treatments in different plant species. Journal of Plant Nutrition 14: 175-185.

Majerowicz, N., Kerbauy, G.B., Nievola, C.C. \& Suzuki, R.M. 2000. Growth and nitrogen metabolism of Catasetum fimbriatum (Orchidaceae) grown with different nitrogen sources. Environmental and Experimental Botany 44: 195-206.
Marschner, H. \& Marschner, P. 2012. Marschner's mineral nutrition of higher plants. 3 ed. Academic Press, London.

Masclaux-Daubresse, C., Daniel-Vedele, F., Dechorgnat, J., Chardon, F., Gaufichon, L. \& Suzuki, A. 2010. Nitrogen uptake, assimilation and remobilization in plants: challenges for sustainable and productive agriculture. Annals of Botany 105: 1141-1158.

Ma, W., Li, J., Qu. B., He, X., Zhao, X., Li, B., Fu, X. \& Tong, Y. 2014. Auxin biosynthetic gene TAR2 is involved in low nitrogen-mediated reprogramming of root architecture in Arabidopsis. Plant Journal 78:70-79.

MCcullough, H. 1967. The determination of ammonia in whole blood by a direct colorimetric method. Clinica Chimica Acta 17(2): 297-304.

Miflin, B.J. \& Habash, D.Z. 2002. The role of glutamine synthetase and glutamate dehydrogenase in nitrogen assimilation and possibilities for improvement in the nitrogen utilization of crops. Journal of Experimental Botany 53(370): 979-987.

Miller, A.J., Fan, X., Orsel, M., Smith, S.J. \& Wells, D.M. 2007. Nitrate transport and signaling Journal of Experimental Botany 58(9): 2297-2306.

Munné-Bosch, S. \& Lalueza, P. 2007. Age-related changes in oxidative stress markers and abscisic acid levels in a drought-tolerant shrub, Cistus clusii grown under mediterranean field conditions. Planta 225: 1039-1049.

Murashige, T. \& Skoog, F. 1962 A revised medium for rapid growth and bio assays with tobacco tissue cultures. Physiologia Plantarum 15(3): 473-497.

Myers, N., Mittermeier, R.A., Mittermeier C.G., Fonseca, G.A.B.da \& Kent, J. 2000. Biodiversity hotspots for conservation priorities. Nature 403: 853-858.

Nievola, C.C., Mercier, H. \& Majerowisz, N. 2001. Levels of nitrogen assimilation in bromeliads with different growth habits. Journal of Plant Nutrition 24(9): 13871387.

Orme, C.D.R., Davies, R.G., Burgess, M., Eigenbrod, F., Pickup, N., Olson, V.A., Webster, A.J., Ding, T-S., Rasmussen, P.C., Ridgely, R.S., Statterfield, A.J., Bennett, P.M., Blackburn, T.M., Gaston, K.J. \& Owens, I.P.F. 2005. Global hotspots of species richness are not congruent with endemism or threat. Nature 436(7053): 1016-1019.

Palatnik, J.F., Carillo, N. \& Valle, E.M. 1999. The role of photosynthetic electron transport in the oxidative degradation of chloroplastic glutamine synthetase. Plant Physiology 121: 471-478.

Parry, M.A., Andralojc, P.J., Mitchell, R.A., Madgwick, P.J. \& Keys, A.J. 2003. Manipulation of Rubisco: the amount, activity, function and regulation. Journal of Experimental Botany 54: 1321-33.

Peeters, K.M.U. \& Van Laere, A.J. 1992. Ammonium and amino acid metabolism in excised leaves of wheat (Triticum aestivum) senescing in the dark. Physiologia Plantarum 84: 243-249. 
Proença, S.L. \& Sajo, M.G. 2007. Anatomia foliar de bromélias ocorrentes em áreas de cerrado do Estado de São Paulo, Brasil. Acta Botanica Brasilica 21(3): 657-673.

Qin, C., Qian, W., Wang, W., Wu, Y., Yu, C., Jiang, X., Wang, D. \& Wu, P. 2008. GDP-mannose pyrophosphorylase is a genetic determinant of ammonium sensitivity in Arabidopsis thaliana. Proceedings of the National Academy of Sciences 105: 18308-18313.

Raab, T.K. \& Terry, N. 1994 Nitrogen-source regulation of growth and photosynthesis in Beta vulgaris L. Plant Physiology 105: 1159-1166.

Rennenberg, H., Wildhagen, H. \& Ehlting, B. 2010. Nitrogen nutrition of pop- lar trees. Plant Biology 12:275-291.

Robinson, S.A., Slade, A.P., Fox, G.G. Phillips, R., Ratcliffe, R.G. \& Stewart, G.R. 1991. The Role of Glutamate Dehydrogenase in Plant Nitrogen Metabolism. Plant Physiology 95: 509-516.

Roosta, H.R. \& Schjoerring, J.K. 2007. Effects of ammonium toxicity on nitrogen metabolism and elemental profile of cucumber plants. Journal of Plant Nutrition 30:1933-1951

Ruzicka, K., Simaskova, M., Duclercq, J., Petrasek, J., Zazımalova, E., Simon, S., Friml, J., Van Montagu, M.C.E., \& Benkova, E. 2009. Cytokinin regulates root meristem activity via modulation of the polar auxin transport. Proceedings of the National Academy of Sciences 106: 4284-4289.

Silva, P., Couto, J. \& Santos, A. 2010. Absorção dos íons amônio e nitrato e seus efeitos no desenvolvimento do girassol em solução nutritiva. Revista de Biologia e Ciências da Terra 10(2): 97-104.

Silva, P.P.A., Kurita, F.M.K. \& Tamaki, V. 2017. In vitro propagation of Ananas comosus var. ananassoides (Baker) Coppens \& F. Leal (Bromeliaceae). Científica 45(3): 313-320.

Silva, P.P.A. \& Tamaki, V. 2012. Micropropagação da bromélia Ananas ananassoides (Baker) L.B. Sm. In: XVI Encontro de Iniciação Científica do Instituto de Botânica. Instituto de Botânica da Secretaria do Meio Ambiente, São Paulo, pp 22.

Skopelitis, D.S., Paranychianakis, N.V., Paschalidis, K.A., Plia- konis, E.D., Delis, I.D., Yakoumakis, D.I., Kouvarakis, A., Papa- dakis, A.K., Stephanou, E.G. e Roubelakis-Angelakisa, K.A. 2006. Abiotic stress generates ROS that signal expression of anionic glutamate dehydrogenases to form glutamate for proline synthesis in tobacco and grapevine. Plant Cell 18: 2767-2781.

Souza, F.V.D., Souza, A.daS., Serejo,J.A.dosS, Souza, E.H.de, Junghans, T.G. \& Silva, M.deJ.de. 2009 Micropropagação do abacaxizeiro e outras bromeliáceas. In: T.G. Junghas \& A.S. Souza (eds.). Aspectos práticos da micropropagação de plantas. Embrapa Mandioca e Fruticultura Tropical, Cruz das Almas, pp. 177-205.
Taiz, L \& Zeiger, E. 2013. Fisiologia Vegetal. 5 ed. Artmed, Porto Alegre.

Tamaki, V., Mercier, H. \& Nievola, C.C. 2007. Cultivo in vitro de clones de Ananas comosus (L.) Merril cultivar Smooth Cayene em diferentes concentrações de macronutrientes. Hoehnea 34(1): 67-73.

Tamaki, V. \& Mercier, H. 2007. Cytokinins and auxin communicate nitrogen availability as long-distance signal molecules in pineapple (Ananas comosus). Journal of Plant Physiology 164(11): 1543-1547.

Tian, Q., Chen, F., Liu, J., Zhang, F. \& Mi, G. 2008 Inhibition of maize root growth by high nitrate supply is correlated with reduced IAA levels in roots. Journal of Plant Physiology 165:942-951.

Walch-Liu, P., Ivanov, I., Filleur, S., Gan, Y., Remans, T. \& Forde, B.G. 2006. Nitrogen regulation of root branching. Annals of Botany 97: 875-881.

Weatherburn, M.W. 1967. Phenol-hypochlorite reaction for determination of ammonia. Analytical Chemistry 39(8): 971-974.

Werner, E.T., Milanez, C.R.D., Mengarda, L.H.G., Vendrame, W.A. \& Cuzzuol, G.R.F. 2010. Meios de cultura, reguladores de crescimento e fontes de nitrogênio na regulação da calogênese do pau-brasil (Caesalpinia echinata Lam.). Acta Botanica Brasílica 24(4): 10461051.

Vidal, E.A., Moyano, T.C., Riveras, E., Contreras-Lopez, O. \& Gutierrez, R.A. 2013. Systems approaches map regulatory networks downstream of the auxin receptor AFB3 in the nitrate response of Arabidopsis thaliana roots. Proceedings of the National Academy of Sciences 10:12840-12845.

Xu, G., Fan, X. \& Miller, A.J. 2012. Plant nitrogen assimilation and use efficiency. Annual Review of Plant Biology 63: 153-182.

Zhang, W., To, J.P.C., Cheng, C.Y., Schaller, G.E. \& Kieber, J.J. 2011. Type-A response regulators are required for proper root apical meristem function through post-transcriptional regulation of PIN auxin efflux carriers. Plant Journal 68: 1-10.

Zhang, W., Swarup, R., Bennett, M., Schaller, G.E. \& Kieber, J.J. 2013. Cytokinin induces cell division in the quiescent center of the Arabidopsis root apical meristem. Current Biology 23: 1979-1989.

Zou, N., Li, B., Dong, G., Kronzucker, H.J. \& Shi, W.M. 2012. Ammonium-induced loss of root gravitropism is related to auxin distribution and TRH1 function, and is uncoupled from the inhibition of root elongation in Arabidopsis. Journal of Experimental Botany 63: 3777 3788 .

Zoucchi, M.R., Silva, M.W., Sibov, S.T. \& Pires, L.L. 2019. Ornamental and landscape potential of a bromeliad native to the Cerrado. Ornamental Horticulturae 25(4): 425-433. 